\title{
The Impact of Financial Sanctions: The Case of Iran 2011-2016
}

Ghasseminejad, Saeed and Mohammad R. Jahan-Parvar

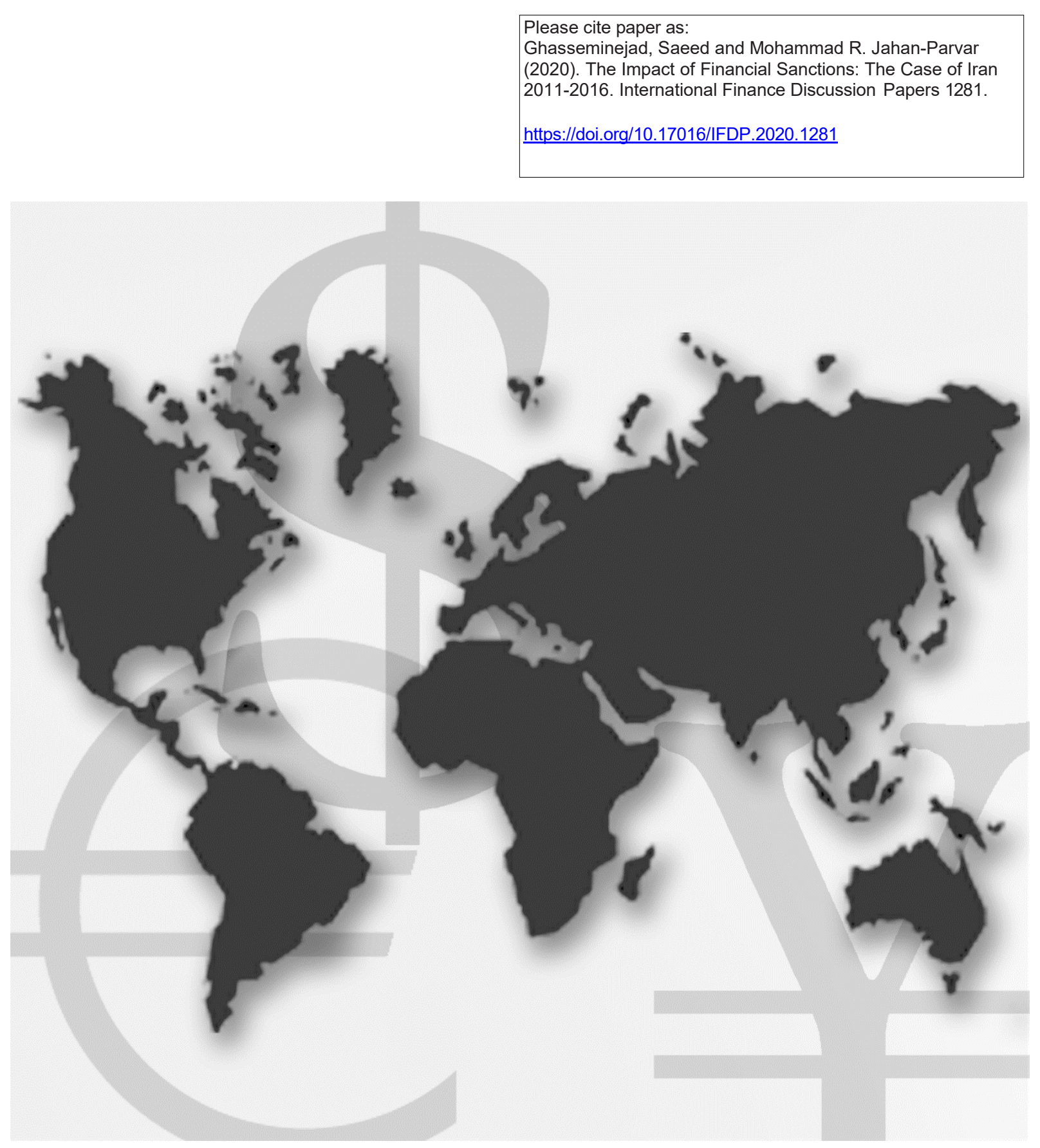

\section{International Finance Discussion Papers}

Board of Governors of the Federal Reserve System

Number 1281

May 2020 


\title{
Board of Governors of the Federal Reserve System \\ International Finance Discussion Papers
}

Number 1281

May 2020

\section{The Impact of Financial Sanctions: The Case of Iran 2011-2016}

\author{
Saeed Ghasseminejad and Mohammad R. Jahan-Parvar
}

NOTE: International Finance Discussion Papers (IFDPs) are preliminary materials circulated to stimulate discussion and critical comment. The analysis and conclusions set forth are those of the authors and do not indicate concurrence by other members of the research staff or the Board of Governors. References in publications to the International Finance Discussion Papers Series (other than acknowledgement) should be cleared with the author(s) to protect the tentative character of these papers. Recent IFDPs are available on the Web at www.federalreserve.gov/pubs/ifdp/. This paper can be downloaded without charge from the Social Science Research Network electronic library at www.ssrn.com. 


\title{
The Impact of Financial Sanctions: The Case of Iran 2011-2016.
}

\author{
January 2020
}

\begin{abstract}
This study provides a detailed analysis of the impact of financial sanctions on publicly traded companies. We consider the effect of imposing and lifting sanctions on the target country's traded equities and examine the differences in the reaction of politically connected firms and those without such connections. The paper focuses on Iran due to (1) its sizable financial markets, (2) imposition of sanctions of varying severity and duration on private and state-owned companies, (3) the significant presence of politically connected firms in the stock market, and (4) the unique event of the 2015 nuclear deal, resulting in fairly rapid lifting of a sizable portion of imposed sanctions. We find that sanctions affect politically connected firms more than ordinary firms, have lasting negative effects on profitability ratios, and that politically connected firms stock prices bounce back more slowly after removal of sanctions. Firms targeted by financial sanctions decrease their leverage and increase their cash holding to manage their perceived increase in risk profile.
\end{abstract}

JEL Classification: D74; H56; F51; G32; G39

KEYwords: Financial Sanctions; capital structure; event study; political connections; Iran; national security 
"Economic sanctions have become a powerful force in service of clear and coordinated foreign policy objectives-smart power for situations where diplomacy alone is insufficient, but military force is not the right response. They must remain a powerful option for decades to come. That is why the lessons we have learned from our experience need to guide our approach to sanctions in the future." Jack Lew, United States Secretary of the Treasury (2013-2017)

"Financial measures have become far more powerful tools of statecraft, and their effects are multiplied in a world defined by economic interdependence we have been able to move away from clunky and heavy-handed instruments of economic power. Sanctions that focus on bad actors within the financial sector are far more precise and far more effective than traditional trade sanctions."

David Cohen, Former Deputy Director of the Central Intelligence Agency and Former Under Secretary of the Treasury for Terrorism and Financial Intelligence

\section{Introduction}

Financial sanctions are fast becoming a potent and widely used foreign policy tool and an alternative to military power projection. They have become progressively more sophisticated, and, thanks to rising interconnection of the global financial system, increasingly effective in targeting specific goals. In recent years, the United States has imposed financial sanctions against individuals and corporate entities in Russia, Myanmar, Nicaragua, Venezuela, and Iran, among others. The economic impact of financial sanction policies, however, is an understudied subject in the literature. In this paper, we provide the a comprehensive documentation of how financial sanctions affect publicly traded firms in a target country. We study the sequence of sanctions, their impact on stock returns of targeted firms and industries, as well as changes to the capital structure and profitability of those firms affected by sanctions. To this end, we focus on a combination of sanctions imposed on Iranian corporations listed in the Tehran Stock Exchange (henceforth, TSE) in the 2011-2016 period. During this time, Iran faced comprehensive and far-reaching economic and financial sanctions in response to its nuclear program.

The reasons for our focus on Iran are fourfold. First, these sanctions delivered their intended goal: The Islamic Republic of Iran suspended much of its nuclear enrichment efforts and resumed negotiation with the United States and five other world powers about its nuclear program. ${ }^{1}$ Second, for an emerging or frontier economy, Iran has a relatively large stock market, and share holding features prominently in financial decisions of the better-off Iranians. As a result, financial sanctions

1 The so-called P5+1 countries are the United States, the United Kingdom, France, Russia, Peoples Republic of China, and Germany. 
have significant impact in Iran's case. In addition, the sanctions regime against Iran was unique because of its length, intensity, and diversity; furnishing us with a natural experiment to observe the full impact of modern financial sanctions on a country. Third, we have access to a unique data set that provides detailed financial information about the universe of publicly traded firms listed in the TSE. Access to these data allows us to carefully measure the impact of sanctions on Iranian firms. Our data set includes both imposition and removal of sanctions. Finally, U.S.-Iran relations and sanctions against Iran are again in the policy-related headlines. Ours is thus a timely study to document and analyze the impact of the previous (successful) round of sanctions. We expect that the lessons from this study contribute to relevant research and policy debates.

This paper presents comprehensive empirical analysis on how different players in the market react to various types of sanctions, and how these sanctions affect a firm's performance and financing decisions. We find that sanctions affect politically connected firms more than ordinary firms, and that they have lasting negative effects that appear in long-term stock returns and profitability ratios. Our results confirm the predictions of financial economic theory in the sense that, not surprisingly, firm management and shareholders facing an episode of well-coordinated and wellexecuted sanctions act as the theory predicts they should. Targeted firms decrease their leverage and increase their cash holding to manage their perceived increased risk. Our results are robust to both imposition and removal of sanctions. Curiously, we find that while removing sanctions lead to positive returns, the magnitude of these positive abnormal returns are smaller for politically connected firms. In other words, politically connected firms demonstrate a smaller bounce back in returns.

This study contributes to several strands of economic research: a) evaluation of economic and financial sanctions, b) political connections of firms and their financial implications, c) capital structure of firms, and d) the nascent literature on the political economy of the Middle East. In this study, we first consider the aggregate effects of economic sanctions on the target country's financial markets. Second, we test whether the reactions of politically connected firms, in this case firms connected to the Iranian "deep state," differ significantly from non-politically connected firms upon imposition or removal of sanctions. Third, we study how financial sanctions affect a firm's capital structure. 
Several studies on economic and financial sanctions approach the subject from international law, international relations, or macroeconomics points of view. International legal research questions the justification and admissibility of sanctions under international law. International relations scholars ask whether, when, and how economic sanctions are successful. Several studies conclude that only harsh measures can convince the target to make a significant change in its plans. Examples include Lam (1990), Hufbauer and Oegg (2003), Hufbauer, Schott, Elliott, and Oegg (2009), and Whang (2010). In a theoretical study, Beladi and Oladi (2009) argue that from the target country point of view, partial compliance plus mild sanctions is an equilibrium outcome and Pareto superior to non-compliance and harsh economic sanctions. Macroeconomic effects of economic sanctions are the subject of several studies. Evenett (2002) investigates the role of U.S. Comprehensive AntiApartheid Act in bringing the apartheid era to an end in South Africa. Neuenkirch and Neumeier (2015) show that, on average, U.N. sanctions decreases the target countrys real per capita GDP growth rate by 2.3 to 3.5 percentage points. They claim that these adverse effects may last as long as a decade. Caruso (2003) shows that U.S. sanctions lead to a 0.5 to 0.9 percentage point reduction in the GDP growth of the target country in a 7-year period, on average. Bapat and Morgan (2009) argue that multilateral sanctions work better than unilateral sanctions. Afesorgbor (2019) shows that imposed sanctions lead to a decrease in trade between the imposer and target while the threat of sanction actually increases the flow of trade. Shirazi, Azarbaiejani, and Sameti (2016) conclude that the sanctions imposed on Iran negatively affected its exports. From 2012 to 2014, the country's exports declined 33 percent on average, totaling USD 104 billion in lost revenues.

A number of studies focus on macroeconomic effects of sanctions imposed on Russia. Barseghyan (2019) shows that counter-sanctions enacted by Russia against agricultural imports boosted productivity and income in that sector, and partially counterbalanced declines in real GDP per capita and FDI net inflows. Golikova and Kuznetsov (2017) use a survey of manufacturing companies in Russia in their qualitative study. They document the claims of surveyed managers who believe that sanctions negatively impact the better-performing, more globalized firms.

Our findings contribute to the literature that focuses on politically connected firms and their characteristics. Fisman (2001); Faccio (2006); Faccio and Parsley (2009); and Acemoglu, Johnson, 
Kermani, Kwak, and Mitton (2016) study the relation between political connections and firms valuation. Goldman, Rocholl, and So (2009) document the role of government officials in allocating contracts to politically connected firms. A higher possibility of a government bailout during episodes of distress is an important factor that increases the value of politically connected firms; see Faccio, Masulis, and McConnell (2006).

A small literature studies the political economy of the Middle East. Among such papers, Berman, Shapiro, and Felter (2011) develop a model of counterinsurgency in Iraq, while Jaeger and Paserman (2008) and Durante and Zhuravskaya (2018) study the Israeli-Palestinian conflict. The reaction of financial markets to political unrest and armed conflict has also garnered some attention in the literature. Guidolin and La Ferrara (2007) conduct an event study analysis of the impact of violent armed and political conflict on private firms. They find that the returns of private firms in Angola were negatively affected by the end of the conflict in that country. In the intersection of political economy and reaction of financial markets to instability, we find two very interesting papers. Acemoglu, Hassan, and Tahoun (2017) study the impact of political uncertainty (in the form of street protests) on the valuation of politically connected firms in Egypt. They find that street protests act as a partial constraint on political rent-seeking. Using a unique event, floating of the Iraqi sovereign debt in financial markets, Chaney (2008) measures the reaction of financial markets to pacification policies in Iraq via the fluctuations of sovereign yield spreads.

Rigorous studies of financial sanctions, however, are scarce. Ahn and Ludema (2017, 2019) measure the impact of targeted sanctions imposed by the United States and European Union against Russian firms. Their findings imply significant costs to target firms and relatively light collateral damage inflicted on the rest of the economy. In a study closely related to ours, Draca, Garred, Stickland, and Warrinnier (2019) measure the returns of a portfolio of firms with links to the Iranian deep state to news coverage of nuclear negotiations. The goal of their paper is measuring the degree of precision of financial sanctions. They investigate the assertion that modern financial sanctions are effective in targeting the intended actors, and impose less costs to the rest of the market participants. They find that at least in Iran's case, sanctions are not as "on target" as one wishes them to be. That said, they find (as we do) clear evidence that the imposed sanctions were quite successful in negatively affecting the market performance of deep-state-connected firms, 
generating an economic incentive for policymakers to negotiate a deal in return for removal of the imposed sanctions. This outcome was the primary target of the U.S. Treasury, and thus indicates success for financial sanction policy. The two studies differ in aims, construction of data, and methods. They are best characterized as complementary: While we focus on longer term effects of sanctions on designated firms and industries (industry-wide vs. individual firm sanctions, the relative importance of first versus subsequent designations, the impact on profitability and capital structure, $\cdots$ ), Draca et al. focus on the short-term impact of news (especially sanction and removal of sanctions announcements) on stock returns of deep-state connected firms, and responses of elite policymakers with economic interest in those firms.

Changes in business environment and firms' response to such changes, through adjustments in capital structure, is an active line of research. Fischer, Heinkel, and Zechner (1989) and Hovakimian, Opler, and Titman (2001) show that firms periodically readjust their capital structure toward a target ratio. The target ratio changes in response to changes in firm's characteristics and business environment. High leverage is associated with higher risk; as a result, when a firm becomes risky one of its options is reducing its leverage. For example, cash flow volatility is associated with lower leverage (Bradley, Jarrell, and Kim, 1984; Wald, 1999; and Booth, Aivazian, DemirgucKunt, and Maksimovic, 2001). Faccio, Lang, and Young (2001) show that in a weak protection environment, higher leverage gives the controlling shareholder more opportunity to expropriate. Boubakri, Cosset, and Saffar (2012) show that firms increase their leverage the more politically connected they become. Boubakri, Ghoul, and Saffar (2013) study the cash-holding behavior of politically connected firms. Faccio (2010) studies firms from 47 countries and finds that politically connected firms have higher leverage. Saeed, Belghitar, and Clark (2015) find that Pakistani firms with political connection had higher leverage between 2002 and 2010. They also find that politically connected firms are less efficient in their investment decisions and political connection is associated with negative firm performance. Our results confirm earlier findings and document that firms facing financial sanctions adjust their capital structure, and such adjustments are more notable for politically connected firms as the primary target of sanctions.

The rest of the paper is structured as follow. In Section 2, we provide a brief overview of Iranian economy, sanctions against Iran, politically connected economic power in Iran, and the nuclear deal. 
Section 3 describes the data and methods used in the study. In Section 4, we discuss our empirical findings. Section 5 concludes.

\section{Historical Background}

In 2011, Irans nominal GDP was USD 583.5 billion and stock market capitalization to GDP ratio stood at 16.40 percent. Between 2011 and 2015, imposed sanctions resulted in nominal GDP level of USD 385.9, a cumulative contraction of over 33 percent. The market capitalization to GDP ratio rose to 25.40 percent by the end of $2015 .^{2}$ Iran is familiar with sanctions. Since the 1979 revolution that abolished the Persian monarchy, the Islamic Republic's domestic and foreign policy has resulted in numerous sanctions imposed against the country. ${ }^{3}$

Against this backdrop of revolution, war, sanctions, and political turmoil, the Tehran Stock Exchange (TSE) has remained active. TSE started operations in February 1968. ${ }^{4}$ In the 1968-79 period, the number of listed companies grew from 6 to 105 with a market capitalization of USD 2.3 billion. Between 1980 and 1990, the TSE was in semi-recess due to political unrest, the Iran-Iraq war, and the anti-capitalist mentality of the new revolutionary government. The number of listed companies declined from 105 to 56, and the trading volume decreased from USD 340 million to USD 10 million per year between 1979 and 1989. After the end of the Iran-Iraq war, the government decided to revive the TSE as a tool for attracting investment and as a venue for privatizing underperforming state-owned companies. The TSE experienced steady growth, and between 2005 and 2015, the government sold 55 percent of its assets in the stock exchange; a total of USD 8.3 billion in 2015 alone. Since 2005, the market capitalization of TSE listed companies ranged between 13 (2007) to 47 percent (2014) of GDP, still lower than the average for advanced economies. ${ }^{5}$

Rumors about an Iranian nuclear program with potential military goals circulated in security and foreign policy circles since the end of the Iran-Iraq war (1980-1988). Starting in the early

2 Source: FRED data bank, Federal Reserve Bank of St. Louis.

3 Table 13 provides a brief description of sanctions imposed on Iran by the United States, United Nations, and European Union between 1979 and 2013.

4 Tehran Stock Exchange, "Tarikhche Bourse Oragh Bahadar Tehran," link: http://www.tse.ir/cms/Default.aspx?tabid=107

5 FRED data bank, Federal Reserve Bank of St. Louis, and The World Bank, "Iran, Overview": http://www. worldbank.org/en/country/iran/overview and The World Bank, "Market capitalization of listed companies (as a percent of GDP)": http://data.worldbank.org/indicator/CM.MKT.LCAP.GD.ZS/countries 
2000s, the United States imposed limited sanctions against the Islamic Republic for supporting terrorism and proliferation of weapons of mass destruction. In 2003, International Atomic Energy Agency (IAEA) confirmed the presence of undeclared nuclear sites in Iran. Negotiation between the Islamic Republic and the United Kingdom, France, and Germany yielded a short-lived freezing of Iran's nuclear program between 2003 and 2005. However, in 2005, Tehran reactivated the program. Following this decision, the United Nations, the United States, and the European Union, in a multilateral international effort, imposed a new series of sanctions on Iran with the goal of suspension of the nuclear program. Between July 2006 and 2012, the UN, the Unites States, and the EU imposed several waves of increasingly severe sanctions and restrictions on technology transfers, investments, financial transactions, revenue repatriation, and on various state and private entities in Iran. Critically, the EU prohibited the import of oil and petrochemical products and related insurance, reinsurance, and transport services and prohibited sales of precious metals to Iran in January 2011, and denied Irans the access to SWIFT facilities in March 2011. By August 2012, the United States demanded that Iran's oil revenues to be kept in escrow accounts.

The financial and oil sanctions proved to be devastatingly effective. Iran was unable to export its hydrocarbon products and could not repatriate its export revenues. Oil export declined from 2.5 million barrels per day (bpd) to about 1 million bpd between 2011 and 2014; see table 1 . The Iranian economy was facing double-digit inflation and a deep recession by 2012. Real GDP growth fell from 5.8 percent in 2010 to 2.6 percent in 2011 and to negative 7.4 percent in 2012; see figure 1. Following this period of intense financial, economic, and political pressure, Iran entered into negotiations with the P5+1. In November 2013, the two sides reached to an agreement, known as the Joint Comprehensive Plan of Action (JCPOA). This agreement suspended a portion of the Islamic Republic's nuclear program. Subsequently, the western powers lifted many of the sanctions imposed in 201113 period. In 2015, both sides signed a comprehensive agreement which removed a more substantial part of sanctions in exchange for suspension or rollback of a larger portion of Iran's nuclear program.

An important feature of Irans economy is the dominant position of firms owned or controlled by the so-called "deep state". There are a number of actors in Iran's deep state, but few of them have as much power and influence as the office of Supreme Leader (Ali Khamenei is the current 
supreme leader and has held this position since 1989) and the Islamic Revolutionary Guards Corps (henceforth, the IRGC). The IRGC is Iran's main military force and a key player in the country's economy and politics. ${ }^{6}$ Between 1979 and early 1990s, the Islamic Republic followed quasi-socialist economic policies, including nationalization of many sectors, intensive price controls, rationing of goods, direct government production of goods and services, and strict control over international trade, among others. Since early 1990s, after the disintegration of the Soviet Union, Islamic Republic started limited liberalization of the economy. Since 2005, more sectors were earmarked for privatization. The primary beneficiary of the privatization, as the Iranian Parliament's Research Center announced, was not the private sector. The quasi-public sector, a euphemism for the IRGC and entities tied to the Supreme Leader, was the most important beneficiary.

A small body of research studies firms with links to the Iranian deep state, i.e., the IRGC and the Supreme Leader's financial holdings. The IRGC got involved in construction projects through its engineering arm, Khatam al-Anbiya since the end of IranIraq war in 1989. In subsequent years, IRGC created numerous subsidiaries that dominate broad swaths of the Iranian economy; see Wehrey, Green, Nichiporuk, Nader, Hansell, Nafisi, and Bohandy (2009). Alfoneh (2010) documents the burden of IRGC's business activities on the country's budget, while Golkar (2015) documents the rent-seeking activities of Basij, the paramilitary arm of the IRGC, leading to a prominent position in many sectors of Iran's economy. The IRGC's involvement in the stock market is focused on strategic industries, such as mining, telecommunication, petrochemicals, and the automotive industry. Ottolenghi, Ghasseminejad, Toumaj, and Fixler (2016) summarized the expert estimates of the percentage of IRGC's control over Iran's economy to be around 25 to 40 percent. Based on these studies, we believe that IRGC owns more than 700 companies (both publicly traded and privately held firms); some were founded by the IRGC, but many were acquired during the privatization push that started in 2000s.

The Supreme Leader also controls significant portions of the Iranian economy. According to the U.S. Treasury, Supreme Leader Ali Khamenei's financial empire is a "shadowy network of offthe-books front companies." 7 The most economically prominent entities controlled by the Supreme

6 Iran maintains a number of parallel armed forces: the regular army, navy, and air force as well as the IRGC's own army, navy, missile force, air force. The IRGC controls the Basij paramilitary force as well.

7 U.S. Department of the Treasury, Press Release, "Treasury Targets Assets of Iranian Leadership," June $4,2013$. (http://www.treasury.gov/press-center/press-releases/Pages/j11968.aspx) 
Leader are the Office for Execution of Imam Khomeini's Order (EIKO); the Mostazafan Foundation; and the Astan Quds Razavi. They are involved in almost every sector of Iran's economy. All three have acquired a considerable share of their assets from the systematic confiscation of dissidents' properties and use their political connections to secure lucrative government contracts, see Maloney (2004). Stecklow, Dehghanpisheh, and Torbati (2013) estimated that EIKO owns about USD 95 billion in assets. Dubowitz and Ghasseminejad (2018, 2019) estimated the value of the assets controlled by the three foundations controlled by the Supreme Leader to be around USD 200 billion.

\section{Data and Methods}

\subsection{Data}

We use Rahavard Novin data bank and the TSE web site to collect market and accounting data at the firm, industry, and market levels from 2000 to the end of 2016. Rahavard Novin data bank provides information coverage similar to CRSP/Compustat data bank in the United States. That said, the depth of coverage in their products are not as extensive as CRSP/Compustat. Where such limitations exist, we discuss them. We use the U.S. Treasury, the European Council, and the United Nation Security Councils press releases to create our sanctions database. We identify the announcement date of each sanction or UNSC resolution and their target which may include an entity, industry, or the whole country. As mentioned earlier, Table 13 in the appendix summarizes all sanctions and their dates.

Next, we identify deep-state-connected firms: companies controlled by the Iranian military (mainly the IRGC) and those controlled by the Supreme Leaders business concerns. To this end, we rely on publicly available data in Iran's Official Journal and the TSE. These sources provide information about major shareholders and board members of listed companies to various degrees. One of the authors leads "the Iranian politically connected firms database" at the Foundation for Defense of Democracies, and we use the findings of this database to create our sample of deep-state firms.

Panel A of table 2 reports summary statistics for all firms in our sample. There were 350 firms 
listed in TSE between 2000 and 2016, of which 52 companies (close to 15 percent) were directly or indirectly controlled by the deep state. The IRGC owned 28 firms and the entities connected to the Supreme Leader owned 24. On Average, deep-state firms account for 23 percent of the end-of-theyear market capitalization of the TSE between 2011-2016. The rest of the sample consists of firms controlled by private investors, other government-controlled entities, or the executive branch. The bulk of the latter category consists of firms controlled by the country's social security and national insurance funds. Panel B of table 2 reports military and deep-state owned firms summary statistics, both before and after designation by one of the designating bodies listed above. We consider a firm to be controlled by the deep state if entities controlled by IRGC or the Supreme Leaders office have more than 50 percent of the common shares of the company or majority of the seats on the board. This classification is a very conservative measure and a rule used by the U.S. Treasury to designate firms effectively controlled by a DSN entity in our period of interest. A militarycontrolled firm is a firm which is either controlled by the IRGC or the Islamic Republic of Irans Armed Forces. ${ }^{8}$ A firm is IRGC-controlled if the IRGC Cooperative Foundation, Basij Cooperative Foundation, Khatam-al-Anbiya Construction Headquarter or entities controlled by them control 50 percent plus 1 shares or majority of the seats on the board. A company is controlled by the armed forces if it is controlled by the armed forces pension fund, the armed forces social security fund, or the armed forces insurance fund. A Supreme Leader-controlled firm is controlled by EIKO, Mostazafan Foundation, Astan Quds Razavi or their subsidiaries.

The sample includes firm-specific, industry-specific, and broad sanctions. Stock exchange transaction data are available for 19952016 period. We consider sanctions imposed after 2005 and use data for the 20002016 interval. This approach yields 19 direct sanctions against 14 unique firm, meaning that either the U.S. or EU sanctioned a firm for the firm's past actions. In a few cases, a firm was sanctioned twice. We found 89 instances of industry sanctions where the U.S. or EU designated a whole industry. In such cases, all publicly traded firms in an industry were subject to sanctions. We eliminate firms that had already been designated at the time that the industry sanction was imposed, shrinking the number of observations to 72 . Following the ratification of JCPOA, the bulk of sanctions were removed in four waves. In the first step, Iran offered a

\footnotetext{
8 The armed forces consists of the IRGC, regular armed forces (army, navy and the air force), and the police.
} 
temporary freeze of portions of its nuclear program in exchange for partial temporary economic sanctions relief (November 24, 2013). Next, Iran agreed to suspend and roll back part of its nuclear program in return for the lifting of international sanctions (July 14, 2015). On October 18, 2015 (Adoption Day), Iran started implementing measures in line with the agreement. The P5+1 took the required regulatory steps to lift or suspend sanctions. Finally, on implementation day (January 16, 2016) the U.S., EU, and UN suspended some sanctions as the IAEA announced Iran completed specific activities required by the JCPOA. These events yield 250 observations related to industry sanctions and 70 observations related to direct sanctions, cumulatively. Panel $\mathrm{C}$ of table 2 reports the summary statistics for these firms. In addition, we study each of the four events independently.

\subsection{Methods}

Our empirical study has two distinct but connected parts. First, we follow the literature in conducting event studies. We investigate the differences across deep-state and ordinary firms returns over imposition or removal of sanction events. For any given event window, we compute abnormal returns (returns above or below expected values, henceforth AR) and aggregate them over an event window $k=1, \cdots, K$. The date $k$ could be set to be before or on the event date. We refer to the aggregated value as cumulative abnormal returns (henceforth, CAR). Our analysis is based on implementing a market-adjusted returns model $^{9}$ where abnormal returns are defined as

$$
A R_{t}^{i}=r_{t}^{i}-r_{t}^{M}
$$

where $r_{t}^{i}$ and $r_{t}^{M}$ are industry or firm $i$ and market (excess) returns, respectively. Cumulative abnormal returns are

$$
C A R_{t+K}^{i}=\sum_{k=1}^{K} A R_{t+k}^{i} .
$$

As a robustness check, we also carried out the analysis using the market model that posits a linear relationship between returns (at firm or industry level) and broad market movements. This method requires statistical support for the market model. Jahan-Parvar and Mohammadi (2013) provide empirical evidence in support of market efficiency for the TSE. Thus, using the market

9 For details of event study analysis, refer to MacKinlay (1997). 
model is justified. These results are available but not reported to save space.

This part of the study then reduces to evaluating whether CARs are statistically different from zero. In other words, does the event in question drive a statistically significant wedge between realized and expected returns over the event window? Addressing this issue requires a search over various window sizes and testing for $C A R=0$ under a number of plausible scenarios.

We consider window sizes ranging between seven business days before to seven business days after the event. The shortest window length studied is four business days. The reason to have long windows is that in some cases, as documented by Draca, Garred, Stickland, and Warrinnier (2019), the negotiations last several days; as a result, it is plausible that the outcome was partially known before the announcement day.

We implement a collection of methods to test whether CARs for sanctions imposed on Iranian companies and sectors were effective. A basic test is a Student- $t$ test, assuming cross-sectional independence between observations, following Serra (2002). Using market-adjusted returns and market models, we compute realized buy-and-hold CARS to form buy-and-hold abnormal return (BHAR). We present market-adjusted returns results; market model results are only for robustness but not reported.

Patell (1976) tests whether average CAR are equal to zero, given uncorrelated and homoscedastic observations, by standardizing individual abnormal returns. Brown and Warner (1980) introduce the crude dependence adjustment (CDA) testing procedure to address correlations across observations. Boehmer, Masumeci, and Poulsen (1991) provide a test procedure which combines standardized residuals test and an estimated variance estimate. Corrado (1989) and Corrado and Zivney (1992) introduce non-parametric rank test for event studies that address the event-induced volatility of rankings. Cowan (1992) introduces a generalized sign test that uses the ratio of positive cumulative abnormal returns over the event window, testing the null hypothesis that the aforementioned ratio and the ratio of positive cumulative abnormal returns over the estimation window should not deviate from each other.

In the second step, we conduct regression analysis to uncover changes in capital structure of firms (deep-state owned or otherwise) during the imposition of sanctions period (2006-2015) and after the removal of sanctions. The methods we use are standard in corporate finance and require 
regressing a firms leverage ratio against a collection of pricing ratios, firm characteristics, and indicator variables, as in standard capital structure papers such as Fischer, Heinkel, and Zechner (1989), Leland (1994, 1998), Hovakimian, Opler, and Titman (2001), and Lemmon, Roberts, and Zender (2008).

\section{Empirical Findings}

We report two distinct set of results: First we report our event study findings, followed by capital structure analysis.

\subsection{Events Studies}

\subsubsection{Imposition of Sanctions}

In the first step, we consider the response of the market to the news that a firm is a target for a direct sanction. These publicly traded firms were either sanctioned by the United States or the European Union. Some of them were sanctioned by both. For the purpose of this study, we have 19 sanction events, of which 14 are first-time designations. In Table 3, we report negative abnormal returns around the announcement day, ranging between negative 0.9 to negative 5.7 percent and statistically different from zero at 1 percent confidence level based on Patell (1976) test. ${ }^{10}$ They indicate that regardless of the window size, direct sanctions lead to significant negative CARs across the sample firms. At the height of the pressure against Iran in 20122013, about 90 Iranian companies were sanctioned. In addition, we study the subsample of first-time designations. We find that firms sanctioned for the first time, on average, experience a far larger and statistically significant decline in CAR than the sample as a whole. CAR declines for firms facing a direct sanction for the first time range between negative 2.4 to negative 8.3 percent. The difference between average CARs for the full sample and the average CAR for the directly sanctioned firms, given the same event window ( $\triangle C A R$ in the table), range between negative 1.2 to negative 3 percent.

A key result that emerges from this study is thatcontrary to a widely held belief in policy circlesunilateral financial sanctions work, at the very least at the firm level, provided that they are

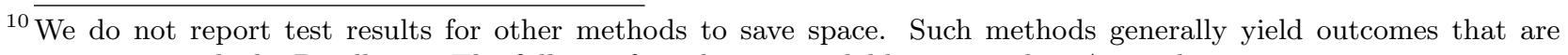
consistent with the Patell test. The full set of results are available in an online Appendix. 
imposed by a sufficiently powerful country (like the United States) or an economicpolitical block (such as the European Union). ${ }^{11}$

Similar to firm-specific sanctions, we expect statistically significant negative abnormal returns for event windows around public announcement of industry-wide sanctions. In addition, we expect that these effects are stronger for the deep-state firms. Table 4 reports the results for all firms that were affected by the industry-wide sanctions. We observe fewer event windows where CARs are statistically different from zero compared with Table 3 (three windows for the full sample and four for first-time sanctions). In addition, the magnitude of these abnormal returns are much smaller than those from direct sanctions against specific firms. This observation holds for both all firms in the sample and for those firms that face sanctions for the first time. Specifically, we consider the first time designation sub-sample. In this exercise, if a firm belongs to the sanctioned industry and if it had already been sanctioned at the time when the industry sanction was announced, we remove the firm from the sample. Like the direct sanctions case, both statistical significance improves and economic magnitudes (abnormal returns) increase. Thus, we again confirm that the first sanction is the most effective through differences table (The last column in Table 4) which reports the changes in differences of CARs across all full sample and first time designees compared over the same event window, up to negative 0.8 percent.

\subsubsection{Removal of Sanctions}

In November 2013, Iran and the P5+1 reached an agreement to temporarily suspend parts of the nuclear program and gradually remove some sanctions. In 2015, both sides signed a comprehensive agreement which removed a more significant portion of sanctions in exchange for suspension or rollback of a more substantial part of Iran's nuclear program. The sanctions removal process went through 4 phases and important dates between 2013 and 2016. Cumulatively, these 4 sanction removal waves provide this study with 250 observations related to industry sanctions and 70 observations related to direct sanctions.

First, we study the removal of sanctions for firms that have been part of the direct sanctions

11 The experience of the United States sanctions against Chinese telecom company ZTE (largely due to its violation of trade restrictions with Iran and North Korea) confirms this observation. See https://www . caixinglobal.com/2019-03-21/one-year-later-zte-still-recovering-from-us-sanctions-101394884.html. 
portfolio. We report these results in Table 5. There are positive CARs associated with waves of sanctions removal. The results are statistically different from zero at conventional significance levels according to most testing procedures and for most event windows. For a two-week [-7; 7$]$ window, the associated cumulative abnormal return is as high as 6 percent.

We then combine all 4 waves to obtain about 250 observations for the industry sanctions portfolio. The results in table 6 in the column titled "Full Sample", show statistically significant and economically positive abnormal returns for this portfolio. For the two-week window, [-7; 7], average CAR are 14.19 percent. For other event windows, CARs remain statistically different from zero at 1 percent confidence level but range between 3.40 to 10.30 percent. We also report the results for each of the four sanction removal events on Table 6 . These results are available on columns bearing the dates of each wave of sanction removal. The first wave of removal of sanctions, the JCPOA event on November 23, 2013, yields the most considerable reaction. The CARs for this date are statistically different from zero and economically significant across all event windows, ranging between 5.60 to 16.85 percent. It is essential to keep in mind that the JCPOA temporarily suspended the sanctions on Iran's automotive and petrochemical sector, accounting for roughly 80 percent of the firms in this portfolio.

In July 2015, P5+1 and Iran officially signed the JCPOA. This event is curiously associated with statistically significant negative abnormal returns for sanctioned industry portfolios. We believe that this portfolio could have already cashed out the maximum benefit from the sanctions relief. Alternatively, market expectations could have been higher than what Iran achieved in the nuclear deal for this portfolio. The results for the next waves of sanctions relief suggest that the latter explanation is more probable. This portfolio experienced a negative 4 percent abnormal return in a two-week window $[-7 ; 7]$ and a negative 10 percent abnormal return in $[0 ; 7]$ window. The combination shows the negative weight is much stronger in the post-event window, a sign of market disappointed about realized outcomes. The industry sanction portfolio had a more positive reaction to the October 18, 2015 event. There are statistically significant positive CARs, as large as 3 percent, across the windows pertaining to this event. We see two negative but statistically not significant CARs.

The last event is the implementation day in January 2016, yielding statistically significant and 
positive CARs for the portfolio across the windows. The two-week window $[-7 ; 7]$ posted 18 percent cumulative abnormal return.

\subsubsection{Differences between Deep-State and Ordinary Firms}

In the next step, we study the impact of sanctions on deep-state firms. We study four portfolios: all firms, IRGC-owned firms, deep-state firms (IRGC and Supreme Leader connected firms together), and ordinary firms with no deep-state connections. We report two sets of results for each portfolio, which we call versions 1 and 2. Version 1 includes all firms in the portfolio, inclusive of those that have been previously sanctioned. In version 2, we only consider firms that face sanctions for the first time. Recall that based on our discussion in section 4.1.1, the first round of sanctions lead to larger cumulative declines in stock returns.

These results are available on Table 7. Across all four panels, it is immediately clear that firms that face sanctions for the first time post a larger loss of value. Version 2 CARs are uniformly larger than their version 1 counterparts. We find that the adverse effect is stronger for the IRGC firms in sanctioned industries, see panel B. For combined events, abnormal returns are -3.6 percent for IRGC firms versus -1.4 percent for the sample of all firms in the $[-7 ; 7]$ window. Similarly, for the first-time designation sample (Version 2), the cumulative abnormal negative returns are negative 8 percent for IRGC firms versus -2 percent for all firms for the $[-7 ; 7]$ window. The same pattern is present for the first designation of the full sample and the deep-state firms, Panel C. The deep-state firms in the $[-7 ; 7]$ window experienced negative 5.3 percent cumulative abnormal returns against negative 2 percent returns for all firms, a negative 3.2 percent percentage points difference on average.

Curiously, the non-deep-state firms sub-sample face a negative 1.5 percent cumulative abnormal return which is 0.5 percentage point less than the whole sample of first designation firms and largely unaffected by first-time designation; see panel D. These results indicate that the effect of industry sanctions on deep-state firms was much stronger.

We investigate the impact of removal of sanctions on the deep-state portfolio cumulative abnormal returns, using a two-week window, $[-7,7]$. While the Supreme Leader-connected firms were quickly delisted as part of the nuclear deal, the IRGC's business empire was not. This issue is 
reflected in our empirical findings, reported in Table 8. In this table, the dependent variable are CARs for a two-week window. The deep-state variable assumes the value of one if the firm is part of the IRGC or supreme leader's business empire. It is zero otherwise. This coefficient for this variable is negative 0.04 and statistically significant. The value of this coefficient is little changed after controlling for size, leverage (debt ratio), and return on assets, implying significant robustness.

In addition to the deep-state variable, the size and leverage (debt ratio) variables also have statistically significant slope parameters. These observations imply that firms with more assets and leverage had higher positive abnormal returns in response to the removal of sanctions. Larger firms are the obvious candidates for imposing sanctions and have been more dependent on foreign trade which explains why they demonstrate a more positive reaction. In addition, the market perceives larger firms to have a higher risk of getting designated. Thus, when the threat of sanctions declines, their stock prices have a larger positive rebound.

Next, we carry out the same analysis for directly sanctioned firms. These results are available in Table 9. The deep-state dummy remains significant; the coefficient value is negative 0.19. After controlling for size, leverage, and profitability, the coefficient is still statistically significant and equal to negative 0.23 , which is large in economic terms.

\subsection{Sanctions and the Capital Structure}

How do sanctions affect the capital structure of target firms? To answer this question, we consider the effect of sanctions on familiar corporate finance quantities such as leverage, cash holding ratio, and profitability of firms. Firms that are subject to sanction reduce their leverage and increase their cash holding as a response to markets perception of their higher levels of risk. We report the empirical findings in support of this assertion in tables 10-12. The regression model in these tables, in general, follows this common specification: ${ }^{12}$

$$
y_{t}^{i}=\alpha_{i}+\sum_{j=1}^{J} \beta_{i, j} x_{t}^{j}+\sum_{k=1}^{K} \gamma_{i, k} D_{t}^{k}+\epsilon_{t}^{i}
$$

where $Y_{t}^{i}$ is one of the corporate finance quantities for company $i$ at time $t$ that we investigate;

\footnotetext{
$12 \overline{\text { See Leland }(1994,1998) \text { and Lemmon, Roberts, }}$ and Zender (2008) for examples of similar analysis.
} 
$x_{t}^{i}$ is an explanatory variable (in the context of this study, we consider corporate finance variables such market-to-book ratio (M2B), return on assets (ROA), size, tangibility, cash flow, leverage, etc). $D_{t}^{i}$ s are dummy variables pertaining to sanction events, deep-state affiliation, and other binary characteristics; $\varepsilon_{t}^{i}$ are i.i.d. standard normal shocks; and $\left(\alpha_{i}, \beta_{i, j}, \gamma_{i, k}\right)$ are company-specific intercepts, factor slope parameters, and dummy variable slope parameters, respectively. To address concerns about possible effects of serial correlation and heteroscedasticity in computation of standard errors, we use the Newey and West (1987) corrected values.

In our first exercise, we study the impact of sanctions on leverage (defined as the sum of long-term debt and short-term debt over the book value of assets), the most direct measure of capital structure. We use four familiar control variables: M2B, which we construct following Frank and Goyal (2009); ROA, which is a profitability measure and defined as operating income before depreciation over the book value of assets; size, defined as the natural logarithm of total assets; and tangibility, defined as net property, plant, and equipment, over the book value of assets. To account for sanctions, we include four dummy variables in two groups. In the first group, we consider direct (firm level) and industry sanctions. For each category, we define "policy" and "post" dummy variables. In each case, policy dummies assume the value 1 for the firms that are subject to industry or direct sanctions and are zero otherwise. "Post" dummy variables for both direct and industry levels assume the value 1 for observations after the date of imposition of sanctions and zero otherwise. This is a difference-in-difference (diff-in-diff) environment. ${ }^{13}$ Both for industry and direct sanctions, the "post" variables measure the net effect of sanction on leverage, while the "policy" variables ensure that the net effect is accounted for both before and after the event.

Our findings, reported in Table 10, indicate that sanctions force firm to reduce their leverage. An interesting finding is that the deep-state portfolio and its subgroup, military firms, have a lower leverage ratio. Deep-state firms have almost 2 percent and military firms have almost 4 percent less leverage than the average. This is in line with the explanation that the market perceives these firms as riskier. At least over this sample period, they keep their leverage low as a risk-management strategy.

Another common measure of capital structure is cash holding ratio (the ratio of cash and cash

\footnotetext{
${ }^{13}$ Imbens and Wooldridge (2009) provide a nice overview of diff-in-diff methods.
} 
equivalents to a company's current liabilities). We report our findings about the impact of sanctions on this variable in Table 11. The dependent variable is cash holding ratio, and explanatory variables are cash-flow ratio, size, market-to-book ratio, and leverage. We include deep-state and sanctions dummy variables in the regression model. There are six sanctions variables in three groups: all sanctions, industry sanctions, and direct sanctions. For each group, we define policy and post dummies the same way that we define them for the leverage study.

We find that firms with higher market-to-book and cash flow ratios have lower cash holding ratios, while larger firms have higher cash holdings. Additionally, we find that deep-state firms have a lower cash holding ratio level, about negative 0.78 less than the average.

The expectation is that the designated firms increase their cash holding ratio in response to sanctions to manage their perceived increase in risk. We find that only the "post" variable in the "all sanctions" category is significant and positive, implying about 1.6 increase in the cash holding ratio. The "post" variable for the two other sanctions categories is positive but not statistically significant.

We investigate the impact of sanctions on profitability of targeted firms. Our findings are available in Table 12. We consider three profitability measures: return on assets, return on sales, and return on working capital. Panel A of table 12 reports the results for all sanctions, while panels $\mathrm{B}$ and $\mathrm{C}$ contain the industry sanctions and direct sanctions results, respectively. Sanction policy and post variables are defined earlier in this section. Our empirical findings imply a substantial and statistically significant negative impact on profitability measures due to "post" sanction variable (which indicates a firms designation). The strongest reactions pertain to direct sanctions, which are associated with a 7 percent drop in return on assets and a 26 percent drop in return on working capital. That said, these results are uniformly negative and statistically significant for "post" dummy variables in "all" and "industry" sanction categories as well. The estimated average coefficients for "all sanctions (post)" variable range between negative 3.8 to negative 15.27 percent. The average coefficient values for "industry sanctions (post)" variable range between negative 3.11 and negative 12.27 percent. 


\section{Conclusion}

In this paper, we provide the first comprehensive documentation of the effects of economic sanctions on financial markets, using the case of Iran equity markets. Iran is a natural candidate to study this topic because of the length and diversity of sanctions imposed on the country, its fairly large economy, and its relatively developed financial markets. In addition, Iran provides an excellent study of what happens once sanctions are relaxed or removed: some of the sanctions imposed on Iran were lifted partially between 2013 and 2016. In addition, we study the differences in the behavior of firms controlled by the deep-state and ordinary firms listed on the Tehran Stock Exchange.

We find that a direct and industry-wide sanctions against a firm or an industry result in significant short-term and long-term abnormal negative returns. These effects are stronger for those firms with deep-state connections. We find that in case of imposing multiple sanctions against a firm, the first sanction is the most effective. We do not find evidence against the consensus that multilateral sanctions are more successful than unilateral ones. However, we show that for this specific sampling period and for sanctions against firms, the first sanction results in the most significant pressure on the target firm.

As expected, removal of sanctions leads to positive abnormal returns. However, the positive abnormal returns are weaker for the deep-state firms. The study finds that firms targeted by sanctions decrease their leverage and increase their cash holding to manage their increased risk, and that the sanctions worsen return ratios. Finally, we show that sanctions significantly adversely affect target firms' profitability.

These results show that sanctions are an effective tool of foreign policy. They cause long-term negative consequences for the target firms, and the adverse outcomes are stronger for malign actors in this paper, those firms owned or connected to the deep-state. 


\section{References}

Acemoglu, D., T. A. Hassan, and A. Tahoun (2017): "The Power of the Street: Evidence from Egypts Arab Spring," The Review of Financial Studies, 31(1), 1-42.

Acemoglu, D., S. Johnson, A. Kermani, J. Kwak, and T. Mitton (2016): "The value of connections in turbulent times: Evidence from the United States," Journal of Financial Economics, 121(2), $368-391$.

Afesorgbor, S. K. (2019): "The impact of economic sanctions on international trade: How do threatened sanctions compare with imposed sanctions?," European Journal of Political Economy, $56,11-26$.

Ahn, D. P., and R. D. Ludema (2017): "The Sword and the Shield: The Economics of Targeted Sanctions," SSRN Working Paper.

(2019): Disrupted Economic Relationships: Disasters, Sanctions, Dissolutionschap. Measuring Smartness: The Economic Impact of Targeted Sanctions against Russia. MIT Press, Boston, MA.

Alfoneh, A. (2010): “The Revolutionary Guards' Looting of Iran's Economy,” Discussion paper, American Enterprise Institute.

Bapat, N. A., And T. C. Morgan (2009): "Multilateral Versus Unilateral Sanctions Reconsidered: A Test Using New Data," International Studies Quarterly, 53(4), 1075-1094.

Barseghyan, G. (2019): "Sanction and counter-sanctions: What did they do?," BOFIT Discussion Paper, 24-2019.

Beladi, H., and R. Oladi (2009): "Partial Compliance with Economic Sanctions," Review of Development Economics, 13(1), 125-133.

Berman, E., J. N. Shapiro, and J. H. Felter (2011): "Can Hearts and Minds Be Bought? The Economics of Counterinsurgency in Iraq," Journal of Political Economy, 119(4), 766-819.

Boehmer, E., J. Masumeci, and A. B. Poulsen (1991): "Event-study methodology under conditions of event-induced variance," Journal of Financial Economics, 30(2), 253 - 272.

Booth, L., V. Aivazian, A. Demirguc-Kunt, and V. Maksimovic (2001): "Capital Structures in Developing Countries," The Journal of Finance, 56(1), 87-130.

Boubakri, N., J.-C. Cosset, and W. Saffar (2012): "The Impact of Political connections on Firms' Operating Performance and Financing Decisions," Journal of Financial Research, 35(3), $397-423$.

Boubakri, N., S. E. Ghoul, and W. SAffar (2013): "Cash holdings of politically connected firms," Journal of Multinational Financial Management, 23(4), 338 - 355.

Bradley, M., G. A. Jarrell, and E. H. Kim (1984): "On the Existence of an Optimal Capital Structure: Theory and Evidence," The Journal of Finance, 39(3), 857-878.

Brown, S. J., AND J. B. WARner (1980): "Measuring security price performance," Journal of Financial Economics, 8(3), 205 - 258. 
Caruso, R. (2003): "The Impact of International Economic Sanctions on Trade: An Empirical Analysis," Peace Economics, Peace Science and Public Policy, 9(2).

Chaney, E. J. (2008): "Assessing Pacification Policy in Iraq: Evidence from Iraqi Financial Markets," Journal of Comparative Economics, 36(1), 1-16.

Corrado, C. J. (1989): "A nonparametric test for abnormal security-price performance in event studies," Journal of Financial Economics, 23(2), 385 - 395.

Corrado, C. J., and T. L. Zivney (1992): "The Specification and Power of the Sign Test in Event Study Hypothesis Tests Using Daily Stock Returns," The Journal of Financial and Quantitative Analysis, 27(3), 465-478.

Cowan, A. R. (1992): "Nonparametric event study tests," Review of Quantitative Finance and Accounting, 2, 343-358.

Draca, M., J. Garred, L. Stickland, and N. Warrinnier (2019): "On Target? Sanctions and the Economic Interests of Elite Policymakers in Iran," Working Paper, University of Warwick.

Dubowitz, M., And S. Ghasseminejad (2018): "Hit Ayatollah Khamenei in His Pocketbook," the Wall Street Journal.

- (2019): "New Sanctions May Deal Heavy Blow to Supreme Leaders Business Empire," Policy report, Foundation for Defense of Democracies, Washington, DC.

Durante, R., and E. Zhuravskaya (2018): "Attack When the World Is Not Watching? US News and the Israeli-Palestinian Conflict," Journal of Political Economy, 126(3), 1085-1133.

Evenett, S. J. (2002): "The Impact of Economic Sanctions on South African Exports," Scottish Journal of Political Economy, 49(5), 557-573.

Faccio, M. (2006): "Politically Connected Firms," American Economic Review, 96, 369-386.

(2010): "Differences between politically connected and nonconnected firms: A crosscountry analysis," Financial Management, 39(3), 905-927.

Faccio, M., L. H. P. Lang, and L. Young (2001): "Dividends and Expropriation," The American Economic Review, 91(1), 54-78.

Faccio, M., R. W. Masulis, and J. J. McConnell (2006): "Political Connections and Corporate Bailouts," The Journal of Finance, 61(6), 2597-2635.

Faccio, M., and D. C. Parsley (2009): "Sudden Deaths: Taking Stock of Geographic Ties," Journal of Financial and Quantitative Analysis, 44(3), 683718.

Fischer, E. O., R. Heinkel, and J. Zechner (1989): "Dynamic Capital Structure Choice: Theory and Tests," The Journal of Finance, 44(1), 19-40.

Fisman, R. (2001): "Estimating the Value of Political Connections," American Economic Review, 91, 1095-1102. 
Frank, M. Z., And V. K. Goyal (2009): "Capital Structure Decisions: Which Factors Are Reliably Important?," Financial Management, 38(1), 1-37.

Goldman, E., J. Rocholl, and J. So (2009): "Do politically connected boards affect firm value?," Review of Financial Studies, 22, 2331-2360.

Golikova, V., And B. Kuznetsov (2017): "Perception of risks associated with economic sanctions: the case of Russian manufacturing," Post-Soviet Affairs, 33(1), 49-62.

Golkar, S. (2015): Captive Society: The Basij Militia and Social Control in Iran. Woodrow Wilson Center Press / Columbia University Press, New York, NY.

Guidolin, M., and E. La Ferrara (2007): "Diamonds Are Forever, Wars Are Not: Is Conflict Bad for Private Firms?," American Economic Review, 97(5), 1978-1993.

Hovakimian, A., T. Opler, and S. Titman (2001): "The Debt-Equity Choice," The Journal of Financial and Quantitative Analysis, 36(1), 1-24.

Hufbauer, G. C., And B. Oegg (2003): "Beyond the Nation-State: Privatization of Economic Sanctions," Middle East Policy, 10(2), 126-134.

Hufbauer, G. C., J. J. Schott, K. A. Elliott, and B. Oegg (2009): "Economic Sanctions Reconsidered," Discussion Paper 3rd Edition, Peterson Institute of International Economics, Washington, DC.

Imbens, G. W., And J. M. Wooldridge (2009): "Recent Developments in the Econometrics of Program Evaluation," Journal of Economic Literature, 47(1), 5-86.

Jaeger, D. A., and M. D. Paserman (2008): "The Cycle of Violence? An Empirical Analysis of Fatalities in the Palestinian-Israeli Conflict," American Economic Review, 98(4), 1591-1604.

Jahan-Parvar, M. R., and H. Mohammadi (2013): "Risk and return in the Tehran stock exchange," The Quarterly Review of Economics and Finance, 53(3), 238 - 256.

LAM, S. L. (1990): "Economic sanctions and the success of foreign policy goals: A critical evaluation," Japan and the World Economy, 2(3), 239 - 248.

Leland, H. E. (1994): "Corporate Debt Value, Bond Covenants, and Optimal Capital Structure," The Journal of Finance, 49(4), 1213-1252.

(1998): "Agency Costs, Risk Management, and Capital Structure," The Journal of Finance, 53(4), 1213-1243.

Lemmon, M. L., M. Roberts, and J. F. Zender (2008): "Back to the Beginning: Persistence and the Cross-Section of Corporate Capital Structure," Journal of Finance, 63(4), 1575-1608.

MacKinlay, A. C. (1997): "Event Studies in Economics and Finance," Journal of Economic Literature, 35(1), 13-39.

Maloney, S. (2004): Gods, Guns, and Globalization: Religious Radicalism and International Political Economychap. Islamism and Irans Post-revolutionary Economy: The case of the Bonyads, pp. 191-218. Lynn Reinner, Boulder, CO. 
Neuenkirch, M., and F. Neumeier (2015): "The impact of UN and US economic sanctions on GDP growth," European Journal of Political Economy, 40, 110 - 125.

Newey, W. K., and K. D. West (1987): "A Simple, Positive Semi-definite, Heteroskedasticity and Autocorrelation Consistent Covariance Matrix," Econometrica, 55, 703-708.

Ottolenghi, E., S. Ghasseminejad, A. Toumaj, and A. Fixler (2016): "How the Nuclear Deal Enriches Iran's Revolutionary Guard Corps," Working Paper, SSRN and FDD.

Patell, J. M. (1976): "Corporate Forecasts of Earnings Per Share and Stock Price Behavior: Empirical Test," Journal of Accounting Research, 14(2), 246-276.

Saeed, A., Y. Belghitar, and E. Clark (2015): "Political Connections and Leverage: Firmlevel Evidence from Pakistan," Managerial and Decision Economics, 36(6), 364-383.

Serra, A. P. (2002): "Event Study Tests: A brief survey," Fep working papers, Universidade do Porto, Faculdade de Economia do Porto.

Shirazi, H., K. Azarbaiejani, and M. Sameti (2016): "The Effect of Economic Sanctions on Iran's Exports," Iranian Economic Review, 20(1), 111-124.

Stecklow, S., B. Dehghanpisheh, and Y. Torbati (2013): "Assets of the Ayatollah," Investigation, Reuters.

WALD, J. K. (1999): "How Firm Characteristics Affects Capital Structure: An International Comparison," Journal of Financial Research, 22(2), 161-187.

Wehrey, F., J. D. Green, B. Nichiporuk, A. Nader, L. Hansell, R. Nafisi, and S. R. Bohandy (2009): The Rise of the Pasdaran: Assessing the Domestic Roles of IranA's Islamic Revolutionary Guards Corps. RAND Corporation, Santa Monica, CA; Arlington, VA; Pittsburgh, PA.

Whang, T. (2010): "Structural estimation of economic sanctions: From initiation to outcomes," Journal of Peace Research, 47(5), 561-573. 
Table 1: The Effect of Sanctions on Iran's Oil Exports

\begin{tabular}{l|ccc}
\hline Buyer & Average Pre-Sanctions (2011) & Average Post Interim Agreement (2014) & Percent Change \\
\hline European Union & 600,000 & Negligible & $-100 \%$ \\
China & 550,000 & 410,000 & $-25 \%$ \\
Japan & 325,000 & 190,000 & $-40 \%$ \\
India & 320,000 & 190,000 & $-40 \%$ \\
South Korea & 230,000 & 130,000 & $-40 \%$ \\
Turkey & 200,000 & 120,000 & $-40 \%$ \\
South Africa & 80,000 & 0 & $-100 \%$ \\
Malaysia & 55,000 & 0 & $-100 \%$ \\
Sri Lanka & 35,000 & Negligible & $-100 \%$ \\
Taiwan & 35,000 & 10,000 & $-70 \%$ \\
Singapore & 20,000 & 0 & $-100 \%$ \\
Other & 55,000 & Negligible & $-100 \%$ \\
Total & 2.505 million & 1.057 million & $-60 \%$ \\
\hline
\end{tabular}

Source: Sanctions Against Iran: A Guide to Targets, Terms, and Timetables, Gary Samore, Belfer Center for Science and International Affairs, Harvard Kennedy School 


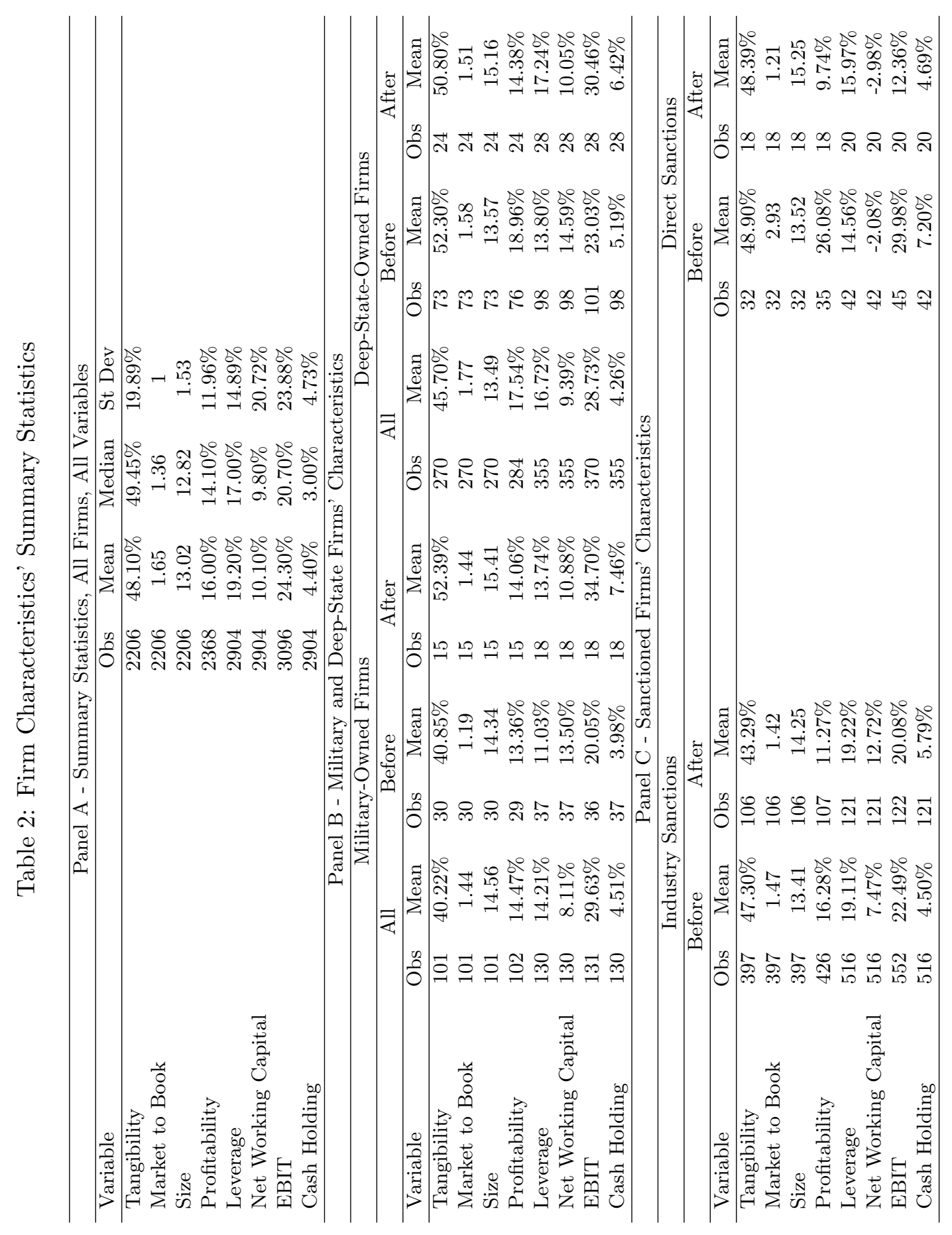

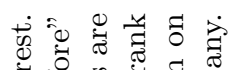

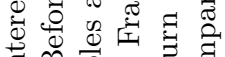
द्व क्षै O $\rightarrow$ 응

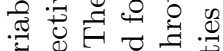
त्र ob की

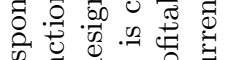
क्षे

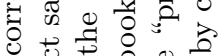

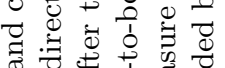

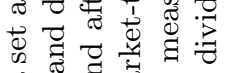

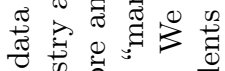

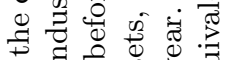
$\therefore$ : 0 पै दै ఫृ है

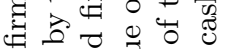

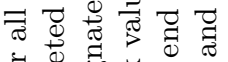
운 50 .

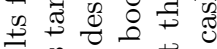
चै है छ

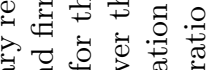
สํ.

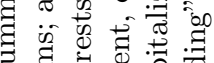
के है 녕

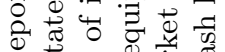
क यक 击 证

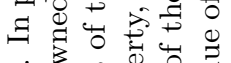
๙

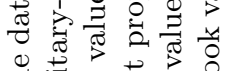

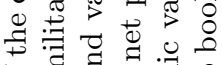

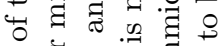
कु

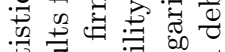

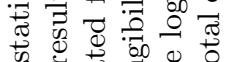
है त. चु 可 का

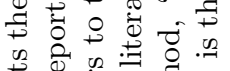

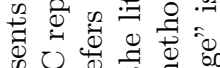

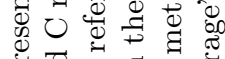
a $\exists \square$ 잉 I ज

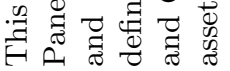


Table 3: Event Study Results: Direct Sanctions

\begin{tabular}{cccccc}
\hline & \multicolumn{3}{c}{ Full Sample } & \multicolumn{3}{c}{ First-Time Sanctioned } \\
Window & CAR & Patell & CAR & Patell & $\Delta$ CAR \\
\hline$[-7 ; 7]$ & $-5.4 \%$ & $* * *$ & $-7.3 \%$ & $* * *$ & $-1.90 \%$ \\
{$[-5 ; 5]$} & $-5 \%$ & $* * *$ & $-7.5 \%$ & $* * *$ & $-2.50 \%$ \\
{$[-4 ; 4]$} & $-5.7 \%$ & $* * *$ & $-8.2 \%$ & $* * *$ & $-2.50 \%$ \\
{$[-3 ; 3]$} & $-0.9 \%$ & $* *$ & $-3.4 \%$ & $* * *$ & $-2.50 \%$ \\
{$[-2 ; 2]$} & $-1.4 \%$ & $* * *$ & $-3.2 \%$ & $* * *$ & $-1.80 \%$ \\
{$[-1 ; 1]$} & $-2 \%$ & $* * *$ & $-3.9 \%$ & $* * *$ & $-2.00 \%$ \\
{$[0 ; 1]$} & $-1.9 \%$ & $* * *$ & $-4.1 \%$ & $* * *$ & $-2.20 \%$ \\
{$[0 ; 3]$} & $-1.2 \%$ & $* * *$ & $-3.1 \%$ & $* * *$ & $-1.90 \%$ \\
{$[0 ; 7]$} & $-1.2 \%$ & $* * *$ & $-2.4 \%$ & $* * *$ & $-1.20 \%$ \\
{$[-7 ; 3]$} & $-5.3 \%$ & $* * *$ & $-8.3 \%$ & $* * *$ & $-3.00 \%$ \\
\hline
\end{tabular}

This table reports the results of applying the Pattel test to cumulative abnormal returns for direct sanction events. $*, * *$, and $* * *$ represent statistical significance of rejecting the null of abnormal returns equal to zero, at 10, 5, and 1 percent levels, respectively. The results for other tests such as $t$-test, CDA, general sign, and Boehmer et al. are available, but not reported. The last column compares the cumulative abnormal returns for different windows for the whole sample of firms targeted by direct sanctions and firms targeted by direct sanctions for the first time. It shows that the effect is stronger for the first-time designated sub-sample. 
Table 4: Event Study Results: Industry Sanctions

\begin{tabular}{cccccc}
\hline & \multicolumn{3}{c}{ Full Sample } & \multicolumn{3}{c}{ First-Time Sanctioned } \\
Window & CAR & Patell & CAR & Patell & $\Delta$ CAR \\
\hline$[-7 ; 7]$ & $-1.50 \%$ & $* * *$ & $-2.00 \%$ & $* * *$ & $-0.60 \%$ \\
{$[-5 ; 5]$} & $-0.40 \%$ & & $-0.70 \%$ & & $-0.30 \%$ \\
{$[-4 ; 4]$} & $0.00 \%$ & & $-0.20 \%$ & & $-0.20 \%$ \\
{$[-3 ; 3]$} & $0.30 \%$ & & $0.00 \%$ & & $-0.30 \%$ \\
{$[0 ; 1]$} & $0.20 \%$ & & $0.00 \%$ & & $-0.20 \%$ \\
{$[0 ; 3]$} & $-0.20 \%$ & & $-0.70 \%$ & $* * *$ & $-0.40 \%$ \\
{$[0 ; 7]$} & $-0.80 \%$ & $* * *$ & $-1.30 \%$ & $* * *$ & $-0.50 \%$ \\
{$[-7 ; 3]$} & $-1.00 \%$ & $* * *$ & $-1.70 \%$ & $* * *$ & $-0.80 \%$ \\
\hline
\end{tabular}

This table provides the results for Patell event-study tests for industry sanctions. *, **, *** represent 10,5 , and 1 percent significance levels, respectively. Results for other tests such as $t$-test, CDA, General Sign, Corrado Rank test, Corrado and Zivney Rank test, and Boehmer et al. are available, but not reported. The last column compares the cumulative abnormal returns for different windows for the whole sample of firms targeted by direct sanctions and firms targeted by direct sanctions for the first time. This comparison implies that the effect is stronger for the first-time designated sub-sample. 
Table 5: Removal of Sanctions: Direct Sanctions

\begin{tabular}{ccccccccc}
\hline Window & Obs & CAR & $t$-test & Patell & Boehmer & Corrado & Zivney & GenSign \\
\hline$-7 ; 7$ & 70 & $6.04 \%$ & $* *$ & $* * *$ & $* * *$ & $* * *$ & $* * *$ & $* * *$ \\
$-5 ; 5$ & 63 & $5.51 \%$ & $* *$ & $* * *$ & $* * *$ & $* * *$ & $* * *$ & $* * *$ \\
$-4 ; 4$ & 65 & $4.25 \%$ & $* *$ & $* * *$ & $* * *$ & $* * *$ & $* * *$ & $* * *$ \\
$-3 ; 3$ & 64 & $5.00 \%$ & $* * *$ & $* * *$ & $* * *$ & $* * *$ & $* * *$ & $* * *$ \\
$-2 ; 2$ & 70 & $3.08 \%$ & $* *$ & $* * *$ & $* * *$ & $* * *$ & $* *$ & $* * *$ \\
$-1 ; 1$ & 54 & $2.21 \%$ & $* *$ & $* * *$ & $* * *$ & $* * *$ & $* * *$ & $* * *$ \\
$0 ; 3$ & 64 & $0.73 \%$ & & $* *$ & & & & $*$ \\
$-7 ; 3$ & 64 & $6.16 \%$ & $* * *$ & $* * *$ & $* * *$ & $* * *$ & $* * *$ & $* * *$ \\
\hline
\end{tabular}

This table provides the results for different event-study tests for the removal of direct sanctions. The included tests are $t$-test, CDA, Patell, General Sign, Corrado Rank test, Corrado and Zivney Rank test, and Boehmer et al. Our inference is based on Patell test results. *, **, *** represent 10, 5, and 1 percent significance levels, respectively. 
Table 6: Removal of Sanctions: Industry Sanctions

\begin{tabular}{ccccccccccc}
\hline & \multicolumn{2}{c}{ Full Sample } & \multicolumn{2}{c}{ 24-Nov-13 } & \multicolumn{2}{c}{ 14-Jul-15 } & \multicolumn{2}{c}{ 18-Oct-15 } & \multicolumn{2}{c}{ 16-Jan-16 } \\
\hline Window & CAR & Patell & CAR & Patell & CAR & Patell & CAR & Patell & CAR & Patell \\
\hline$[-7 ; 7]$ & $14.19 \%$ & $* * *$ & $16.85 \%$ & $* * *$ & $-4.09 \%$ & $* * *$ & $2.82 \%$ & $* * *$ & $18.44 \%$ & $* * *$ \\
{$[-5 ; 5]$} & $10.12 \%$ & $* * *$ & $13.07 \%$ & $* * *$ & $-6.21 \%$ & $* * *$ & $1.58 \%$ & $* * *$ & $11.26 \%$ & $* * *$ \\
{$[-4 ; 4]$} & $9.53 \%$ & $* * *$ & $12.71 \%$ & $* * *$ & $-5.41 \%$ & $* * *$ & $2.05 \%$ & $* * *$ & $9.47 \%$ & $* * *$ \\
{$[-3 ; 3]$} & $7.50 \%$ & $* * *$ & $10.19 \%$ & $* * *$ & $-0.99 \%$ & $* * *$ & $2.74 \%$ & $* * *$ & $6.73 \%$ & $* * *$ \\
{$[-2 ; 2]$} & $4.85 \%$ & $* * *$ & $7.42 \%$ & $* * *$ & $-0.19 \%$ & $* * *$ & $2.88 \%$ & $* * *$ & $1.93 \%$ & $* * *$ \\
{$[0 ; 3]$} & $3.40 \%$ & $* * *$ & $5.60 \%$ & $* * *$ & $-2.95 \%$ & $* * *$ & $-1.58 \%$ & & $3.81 \%$ & $* * *$ \\
{$[0 ; 7]$} & $7.27 \%$ & $* * *$ & $9.01 \%$ & $* * *$ & $-10.23 \%$ & $* * *$ & $-1.64 \%$ & & $11.31 \%$ & $* * *$ \\
{$[-7 ; 3]$} & $10.30 \%$ & $* * *$ & $13.20 \%$ & $* * *$ & $2.99 \%$ & $* *$ & $2.95 \%$ & $* * *$ & $11.62 \%$ & $* * *$ \\
\hline
\end{tabular}

This table reports the results for applying the Patell event-study test for the removal of industry sanctions across various event windows and event dates. ${ }^{*}, * *, * * *$ represent 10,5 , and 1 percent significance levels, respectively. Other tests results such as $t$-test, CDA, General Sign, Corrado rank test, Corrado and Zivney rank test, and Boehmer et al. are available, but not reported. 
Table 7: Deep-State Firms: Industry Sanctions

\begin{tabular}{ccccccccc}
\hline & \multicolumn{3}{c}{ Panel A: All Firms } & \multicolumn{3}{c}{ Panel B: IRGC Firms } \\
\hline & \multicolumn{2}{c}{ Version 1 } & \multicolumn{2}{c}{ Version 2 } & \multicolumn{2}{c}{ Version 1 } & \multicolumn{2}{c}{ Version 2 } \\
\hline Window & CAR & Patell & CAR & Patell & CAR & Patell & CAR & Patell \\
\hline$[-7,7]$ & $-1.5 \%$ & $* * *$ & $-2.0 \%$ & $* * *$ & $-3.6 \%$ & $* * *$ & $-8.0 \%$ & $* * *$ \\
{$[0,7]$} & $-0.8 \%$ & $* * *$ & $-1.3 \%$ & $* * *$ & $-2.7 \%$ & & $-5.3 \%$ & $* *$ \\
{$[-7,3]$} & $-1.0 \%$ & $* * *$ & $-1.8 \%$ & $* * *$ & $0.5 \%$ & & $-3.1 \%$ & $* * *$ \\
\hline \multicolumn{4}{c}{ Panel C: Deep-State Firms } & \multicolumn{2}{c}{ Panel D: Non-Deep-State Firms } \\
\hline \multicolumn{4}{c}{ Version 1 } & \multicolumn{2}{c}{ Version 2 } & \multicolumn{2}{c}{ Version 1 } & \multicolumn{2}{c}{ Version 2 } \\
\hline Window & CAR & Patell & CAR & Patell & CAR & Patell & CAR & Patell \\
\hline$[-7,7]$ & $-1.4 \%$ & $* * *$ & $-5.3 \%$ & $* * *$ & $-1.5 \%$ & $* * *$ & $-1.5 \%$ & $* *$ \\
{$[0,7]$} & $-0.9 \%$ & & $-2.8 \%$ & $*$ & $-0.7 \%$ & $* * *$ & $-1.0 \%$ & $* * *$ \\
{$[-7,3]$} & $0.8 \%$ & & $-2.2 \%$ & $* * *$ & $-1.6 \%$ & $* *$ & $-1.6 \%$ & $* *$ \\
\hline
\end{tabular}

This table reports results for all firms targeted by industry sanctions (blanket sanctions). Version 1 looks at all firms while Version 2 only looks at firms which have not been previously sanctioned (first time designations). 
Table 8: CAR Analysis: Deep-State Firms - Industry Sanctions Delisting

\begin{tabular}{lcccc}
\hline \multicolumn{1}{c}{ Variable } & Model I & Model II & Model III & Model IV \\
\hline Deep State & -0.041 & -0.048 & -0.042 & -0.049 \\
& $(1.81)^{*}$ & $(1.69)^{*}$ & $(1.47)$ & $(1.67)^{*}$ \\
Size & & 0.016 & 0.016 & 0.016 \\
& & $(2.61)^{* * *}$ & $(2.65)^{* * *}$ & $(2.66)^{* * *}$ \\
Debt Ratio & & & & 0.119 \\
& & & & $(2.09)^{* *}$ \\
ROA & & & 0.000 & 0.001 \\
& & & $(0.14)$ & $(0.99)$ \\
$R^{2}$ & 0.38 & 0.43 & 0.43 & 0.43 \\
$N$ & 200 & 151 & 145 & 145 \\
\hline
\end{tabular}

This table uses the cumulative abnormal return for delisting of the firms targeted by industry sanctions over a twoweek window $[-7 ; 7]$ as the dependent variable. The statistical model fitted to the data is $C A R_{t}^{i}=\alpha+\sum_{j=1}^{J} \beta_{i, j} f_{t}^{j}+$ $\sum_{k=1}^{K} \gamma_{i, k} D_{t}^{k}+\epsilon_{t}^{i}$. $f_{t}^{j}$ is variable $j$ at time $t$, and $D_{t}^{k}$ is an indicator function $\mathrm{k}$ at time $t$. $N$ is the number of firms. We report average values for slope parameters. We report Student- $t$ statistics based on Newey-West standard errors. *, $* *$, and $* * *$ imply statistical significance of the estimated parameters at 10,5 , and $1 \%$ confidence level, respectively. This includes all four waves of delisting from 2013 to 2016 . Observations include all waves of sanction removal times $N$. 
Table 9: CAR Analysis: Deep-State Firms - Direct Sanctions Delisting

\begin{tabular}{lcccc}
\hline \multicolumn{1}{c}{ Variable } & Model I & Model II & Model III & Model IV \\
\hline Deep State & -0.197 & -0.232 & -0.232 & -0.228 \\
& $(1.96)^{*}$ & $(2.35)^{* *}$ & $(2.27)^{* *}$ & $(2.21)^{* *}$ \\
Size & & -0.026 & -0.025 & -0.024 \\
& & $(1.62)$ & $(1.63)$ & $(1.37)$ \\
Debt Ratio & & & -0.005 & -0.109 \\
& & & $(0.06)$ & $(0.43)$ \\
ROA & & & & -0.004 \\
& & & & $(0.58)$ \\
$R^{2}$ & 0.43 & 0.50 & 0.50 & 0.51 \\
$N$ & 22 & 21 & 21 & 21 \\
\hline
\end{tabular}

This table uses the cumulative abnormal return for delisting of the firms targeted by direct sanctions over a two-week window $[-7 ; 7]$ as the dependent variable. The statistical model fitted to the data is $C A R_{t}^{i}=\alpha+\sum_{j=1}^{J} \beta_{i, j} f_{t}^{j}+$ $\sum_{k=1}^{K} \gamma_{i, k} D_{t}^{k}+\epsilon_{t}^{i} . f_{t}^{j}$ is variable $j$ at time $t$, and $D_{t}^{k}$ is an indicator function $\mathrm{k}$ at time $t$. We report average values for slope parameters. We report Student- $t$ statistics based on Newey-West standard errors. *, **, and *** imply statistical significance of the estimated parameters at 10,5, and $1 \%$ confidence level, respectively. This includes all four waves of delisting from 2013 to 2016 . Observations include all waves of sanction removal times $N$. 
Table 10: Leverage Analysis

\begin{tabular}{|c|c|c|c|c|c|}
\hline & Leverage & Leverage & Leverage & Leverage & Leverage \\
\hline \multirow[t]{2}{*}{ M2B } & -1.643 & -1.631 & -1.693 & -1.609 & -1.666 \\
\hline & $(2.66)^{* * *}$ & $(2.58)^{* * *}$ & $(2.74)^{* * *}$ & $(2.62)^{* * *}$ & $(2.70)^{* * *}$ \\
\hline \multirow[t]{2}{*}{$\mathrm{ROA}$} & -0.612 & -0.617 & -0.613 & -0.613 & -0.612 \\
\hline & $(16.99)^{* * *}$ & $(16.69)^{* * *}$ & $(16.99)^{* * *}$ & $(17.06)^{* * *}$ & $(16.96)^{* * *}$ \\
\hline \multirow[t]{2}{*}{ Size } & 0.522 & 0.507 & 0.526 & 0.547 & 0.628 \\
\hline & $(2.15)^{* *}$ & $(2.03)^{* *}$ & $(2.14)^{* *}$ & $(2.24)^{* *}$ & $(2.57)^{* *}$ \\
\hline \multirow[t]{2}{*}{ Tangibility } & 3.045 & 2.620 & 3.089 & 2.801 & 2.634 \\
\hline & $(1.81)^{*}$ & $(1.52)$ & $(1.83)^{*}$ & $(1.65)^{*}$ & $(1.55)$ \\
\hline \multirow[t]{2}{*}{ Ind. Sanction (Policy) } & & -12.260 & & & \\
\hline & & $(2.90)^{* * *}$ & & & \\
\hline \multirow[t]{2}{*}{ Ind. Sanction (Post) } & & -2.194 & & & \\
\hline & & $(1.36)$ & & & \\
\hline \multirow[t]{2}{*}{ Direct Sanction (Policy) } & & & 3.890 & & \\
\hline & & & $(1.82)^{*}$ & & \\
\hline \multirow[t]{2}{*}{ Direct Sanction (Post) } & & & -5.162 & & \\
\hline & & & $(1.90)^{*}$ & & \\
\hline \multirow[t]{2}{*}{ Deep State } & & & & -1.748 & \\
\hline & & & & $(2.06)^{* *}$ & \\
\hline \multirow[t]{2}{*}{ Military } & & & & & -4.368 \\
\hline & & & & & $(4.05)^{* * *}$ \\
\hline$R^{2}$ & 0.34 & 0.33 & 0.34 & 0.34 & 0.34 \\
\hline$N$ & 2,155 & 2,105 & 2,155 & 2,155 & 2,155 \\
\hline
\end{tabular}

This table reports the regression analysis results for the effect of sanctions on leverage. The dependent variable is leverage, which is defined as the sum of long-term debt and short-term debt over the book value of assets. The statistical model fitted to the data is leverage $e_{t}^{i}=\alpha+\sum_{j=1}^{J} \beta_{i, j} f_{t}^{j}+\sum_{k=1}^{K} \gamma_{i, k} D_{t}^{k}+\epsilon_{t}^{i}$. Explanatory variables, $f_{t}^{j}$, are Profitability (return on assets) defined as operating income before depreciation over the book value of assets, Firm size defined as the natural logarithm of total assets, Tangibility: defined as net property, plant, and equipment, over the book value of assets, Market-to-book ratio is constructed as in Frank and Goyal (2009). $D_{t}^{k} \mathrm{~s}$ are indicator functions $\mathrm{k}$ at time t. Deep state is 1 if firms is part of the deep-state portfolio. Military is a dummy variable and is 1 if the firm belongs to a military holding. Industry (direct) Sanction Policy is a dummy variable which is always 1 for the firms subject to industry (direct) sanctions and zero otherwise. Industry (direct) Sanction Post is 1 for firms subject to industry (direct) sanctions after time t at which the sanction was imposed and zero otherwise. We report average values for slope parameters. We report Student- $t$ statistics based on Newey-West standard errors. *, **, and *** imply statistical significance of the estimated parameters at 10,5 , and $1 \%$ confidence level, respectively. 
Table 11: Cash-Holding Analysis

\begin{tabular}{|c|c|c|c|c|c|c|}
\hline & Model I & Model II & Model III & Model IV & Model V & Model VI \\
\hline \multirow[t]{2}{*}{ M2B } & 0.869 & 0.872 & 0.872 & 0.862 & 0.883 & 0.869 \\
\hline & $(4.49)^{* * *}$ & $(4.45)^{* * *}$ & $(4.46)^{* * *}$ & $(4.40)^{* * *}$ & $(4.51)^{* * *}$ & $(4.51)^{* * *}$ \\
\hline \multirow[t]{2}{*}{ Cash Flow Ratio } & 1.381 & 1.367 & 1.368 & 1.359 & 1.392 & 1.401 \\
\hline & $(3.55)^{* * *}$ & $(3.59)^{* * *}$ & $(3.59)^{* * *}$ & $(3.56)^{* * *}$ & $(3.58)^{* * *}$ & $(3.61)^{* * *}$ \\
\hline \multirow[t]{2}{*}{ Leverage } & -0.010 & -0.011 & -0.011 & -0.011 & -0.010 & -0.010 \\
\hline & $(1.23)$ & $(1.34)$ & $(1.33)$ & $(1.37)$ & $(1.17)$ & $(1.19)$ \\
\hline \multirow[t]{2}{*}{ Size } & -0.281 & -0.286 & -0.287 & -0.274 & -0.291 & -0.271 \\
\hline & $(2.63)^{* * *}$ & $(2.73)^{* * *}$ & $(2.72)^{* * *}$ & $(2.45)^{* *}$ & $(2.65)^{* * *}$ & $(2.52)^{* *}$ \\
\hline \multirow[t]{2}{*}{ Sanction } & & 1.269 & & & & \\
\hline & & $(1.88)^{*}$ & & & & \\
\hline \multirow[t]{2}{*}{ All Sanction (Policy) } & & & 0.272 & & & \\
\hline & & & $(0.31)$ & & & \\
\hline \multirow[t]{2}{*}{ All Sanction (Post) } & & & 1.231 & & & \\
\hline & & & $(1.70)^{*}$ & & & \\
\hline \multirow[t]{2}{*}{ Ind. Sanction (Policy) } & & & & -0.003 & & \\
\hline & & & & $(0.00)$ & & \\
\hline \multirow[t]{2}{*}{ Ind. Sanction (Post) } & & & & 1.173 & & \\
\hline & & & & $(1.52)$ & & \\
\hline \multirow[t]{2}{*}{ Dir. Sanction (Policy) } & & & & & -0.313 & \\
\hline & & & & & $(0.29)$ & \\
\hline \multirow[t]{2}{*}{ Dir. Sanction (Post) } & & & & & 1.569 & \\
\hline & & & & & $(1.10)$ & \\
\hline \multirow[t]{2}{*}{ Deep State } & & & & & & -0.771 \\
\hline & & & & & & $(1.99)^{* *}$ \\
\hline$R^{2}$ & 0.19 & 0.19 & 0.19 & 0.19 & 0.19 & 0.19 \\
\hline$N$ & 1,610 & 1,610 & 1,610 & 1,610 & 1,610 & 1,610 \\
\hline
\end{tabular}

This table analyzes the effect of sanction on cash holding ratios (cash and cash equivalents divided by current liabilities of a company). The statistical model fitted to the data is $\operatorname{cash}_{t}^{i}=\alpha+\sum_{j=1}^{J} \beta_{i, j} f_{t}^{j}+\sum_{k=1}^{K} \gamma_{i, k} D_{t}^{k}+\epsilon_{t}^{i}$. Cash represents cash holdings by the company $i$ at time $t$, and $f_{t}^{j}$ is variable $j$ at time $t$, and $D_{t}^{k}$ is an indicator function $k$ at time $t$. We report average values for slope parameters. We report Student- $t$ statistics based on Newey-West standard errors. *, **, and *** imply statistical significance of the estimated parameters at 10, 5, and $1 \%$ confidence level, respectively. 
Table 12: Profitability Measures Analysis

\begin{tabular}{|c|c|c|c|}
\hline \multicolumn{4}{|c|}{ Panel A - All Sanctions } \\
\hline & ROA & RWC & ROS \\
\hline \multirow[t]{2}{*}{ Size } & 0.222 & 0.389 & 3.675 \\
\hline & $(1.08)$ & $(0.65)$ & $(6.86)^{* * *}$ \\
\hline \multirow[t]{2}{*}{ All Sanctions (Policy) } & 0.651 & 20.382 & 1.296 \\
\hline & $(0.23)$ & $(1.67)^{*}$ & $(0.41)$ \\
\hline \multirow[t]{2}{*}{ All Sanctions (Post) } & -3.788 & -15.276 & -5.830 \\
\hline & $(2.50)^{* *}$ & $(3.78)^{* * *}$ & $(1.88)^{*}$ \\
\hline$R^{2}$ & 0.24 & 0.28 & 0.26 \\
\hline$N$ & 2,204 & 2,204 & 2,204 \\
\hline \multicolumn{4}{|c|}{ Panel B - Industry Sanctions } \\
\hline & ROA & RWC & $\mathrm{ROS}$ \\
\hline \multirow[t]{2}{*}{ Size } & 0.202 & 0.384 & 3.593 \\
\hline & $(0.98)$ & $(0.64)$ & $(6.85)^{* * *}$ \\
\hline \multirow[t]{2}{*}{ Industry Sanction (Policy) } & 0.841 & 6.321 & -7.202 \\
\hline & $(0.32)$ & $(1.12)$ & $(1.08)$ \\
\hline \multirow[t]{2}{*}{ Industry Sanction (Post) } & -3.107 & -12.274 & -6.064 \\
\hline & $(1.86)^{*}$ & $(2.89)^{* * *}$ & $(1.83)^{*}$ \\
\hline$R^{2}$ & 0.24 & 0.28 & 0.26 \\
\hline$N$ & 2,204 & 2,204 & 2,204 \\
\hline \multicolumn{4}{|c|}{ Panel C - Direct Sanctions } \\
\hline & ROA & RWC & ROS \\
\hline \multirow[t]{2}{*}{ Size } & 0.242 & 0.437 & 3.644 \\
\hline & $(1.17)$ & $(0.72)$ & $(6.96)^{* * *}$ \\
\hline \multirow[t]{2}{*}{ Direct Sanction (Policy) } & 2.072 & 16.590 & 4.618 \\
\hline & $(0.81)$ & $(1.68)^{*}$ & $(1.73)^{*}$ \\
\hline \multirow[t]{2}{*}{ Direct Sanction (Post) } & -7.156 & -26.842 & -4.329 \\
\hline & $(2.38)^{* *}$ & $(2.41)^{* *}$ & $(0.47)$ \\
\hline$R^{2}$ & 0.24 & 0.28 & 0.25 \\
\hline$N$ & 2,204 & 2,204 & 2,204 \\
\hline
\end{tabular}

Dependent variables are the return on assets, return on working capital, and return on sales. The statistical model fitted to the data is profit $t_{t}^{i}=\alpha+\sum_{j=1}^{J} \beta_{i, j} f_{t}^{j}+\sum_{k=1}^{K} \gamma_{i, k} D_{t}^{k}+\epsilon_{t}^{i} . f_{t}^{j}$ is an explanatory variable $j$ at time $t$, and $D_{t}^{k}$ is an indicator function $k$ at time $t$. We report average values for slope parameters. We report Student- $t$ statistics based on Newey-West standard errors. *, **, and *** imply statistical significance of the estimated parameters at 10, 5, and $1 \%$ confidence level, respectively. The three panels study the effect of all sanctions, industry sanctions, and direct sanction. Policy dummy variable assumes the value 1 for all the designated firms and is zero otherwise. The "post" dummy variable assumes the value 1 only for designated firms from the announcement of a designation to the end of the sample and is zero otherwise. 
Figure 1: Changes in real GDP growth

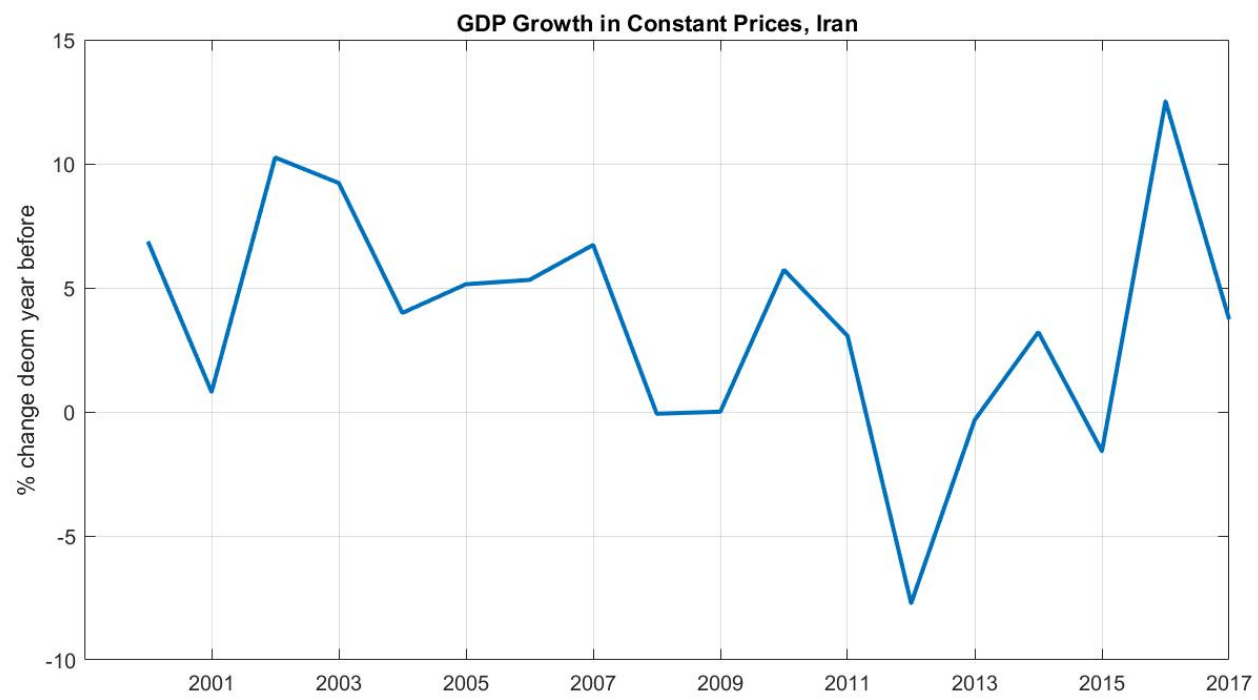

Islamic Republic of Iran's GDP in constant prices year-on-year growth rate between 2000 and 2017. Source: FRED Databank, FRB St. Louis.

\section{The Appendix}




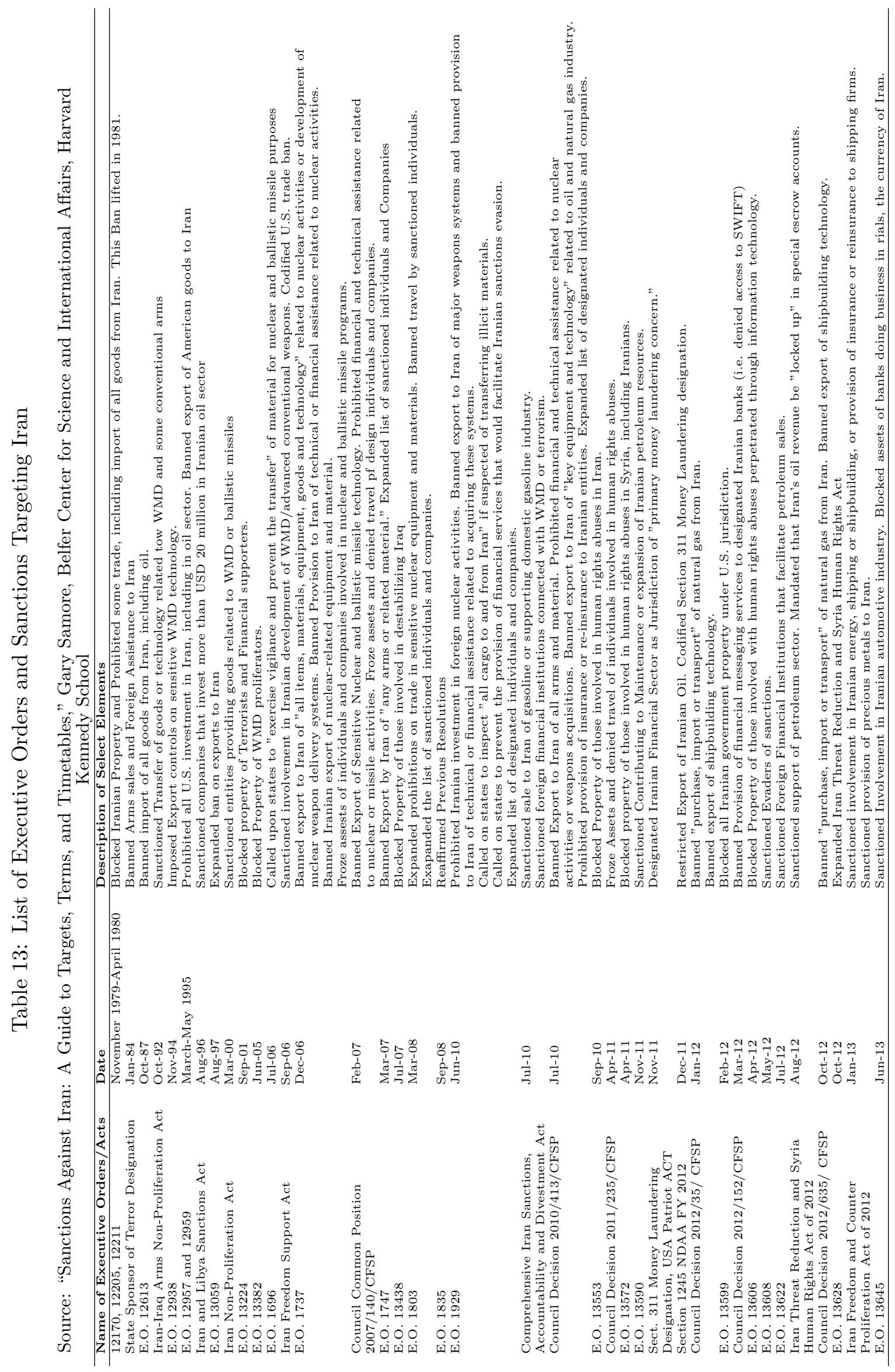

